\title{
Evidence gaps and biodiversity threats facing the marine environment of the United Kingdom's Overseas Territories
}

\author{
Bethan C. O'Leary ${ }^{1}$ (D) Philip Fieldhouse ${ }^{1} \cdot$ Colin J. McClean $^{1}$ (D) . Adriana E. S. Ford ${ }^{2}$ (D) . \\ Polly Burns ${ }^{1}$. Julie P. Hawkins ${ }^{1}$. Callum M. Roberts ${ }^{1}$ (D)
}

Received: 30 January 2018 / Revised: 4 October 2018 / Accepted: 9 November 2018 /

Published online: 28 November 2018

(c) The Author(s) 2018

\begin{abstract}
Understanding the evidence base and identifying threats to the marine environment is critical to ensure cost-effective management and to identify priorities for future research. The United Kingdom (UK) government is responsible for approximately $2 \%$ of the world's oceans, most of which belongs to its 14 Overseas Territories (UKOTs). Containing biodiversity of global significance, and far in excess of the UK mainland's domestic species, there has recently been a strong desire from many of the UKOTs, the UK Government, and NGOs to improve marine management in these places. Implementing evidence-based marine policy is, however, challenged by the disparate nature of scientific research in the UKOTs and knowledge gaps about the threats they face. Here, we address these issues by systematically searching for scientific literature which has examined UKOT marine biodiversity and by exploring publicly available spatial threat data. We find that UKOT marine biodiversity has received consistent, but largely low, levels of scientific interest, and there is considerable geographical and subject bias in research effort. Of particular concern is the lack of research focus on management or threats to biodiversity. The extent and intensity of threats vary amongst and within the UKOTs but unsurprisingly, climate change associated threats affect them all and direct human stressors are more prevalent in those with higher human populations. To meet global goals for effective conservation and management, there is an urgent need for additional and continued investment in research and management in the Overseas Territories, particularly those that have been of lesser focus.
\end{abstract}

Keywords Anthropogenic threats · Marine biodiversity conservation · Evidence base $\cdot$ Gap analysis $\cdot$ Research synthesis · UKOTs

Communicated by Astrid van Teeffelen.

This article belongs to the Topical Collection: Coastal and marine biodiversity.

Electronic supplementary material The online version of this article (https://doi.org/10.1007/s1053 1-018-1660-5) contains supplementary material, which is available to authorized users.

Bethan C. O'Leary

bethan.oleary@york.ac.uk

Extended author information available on the last page of the article 


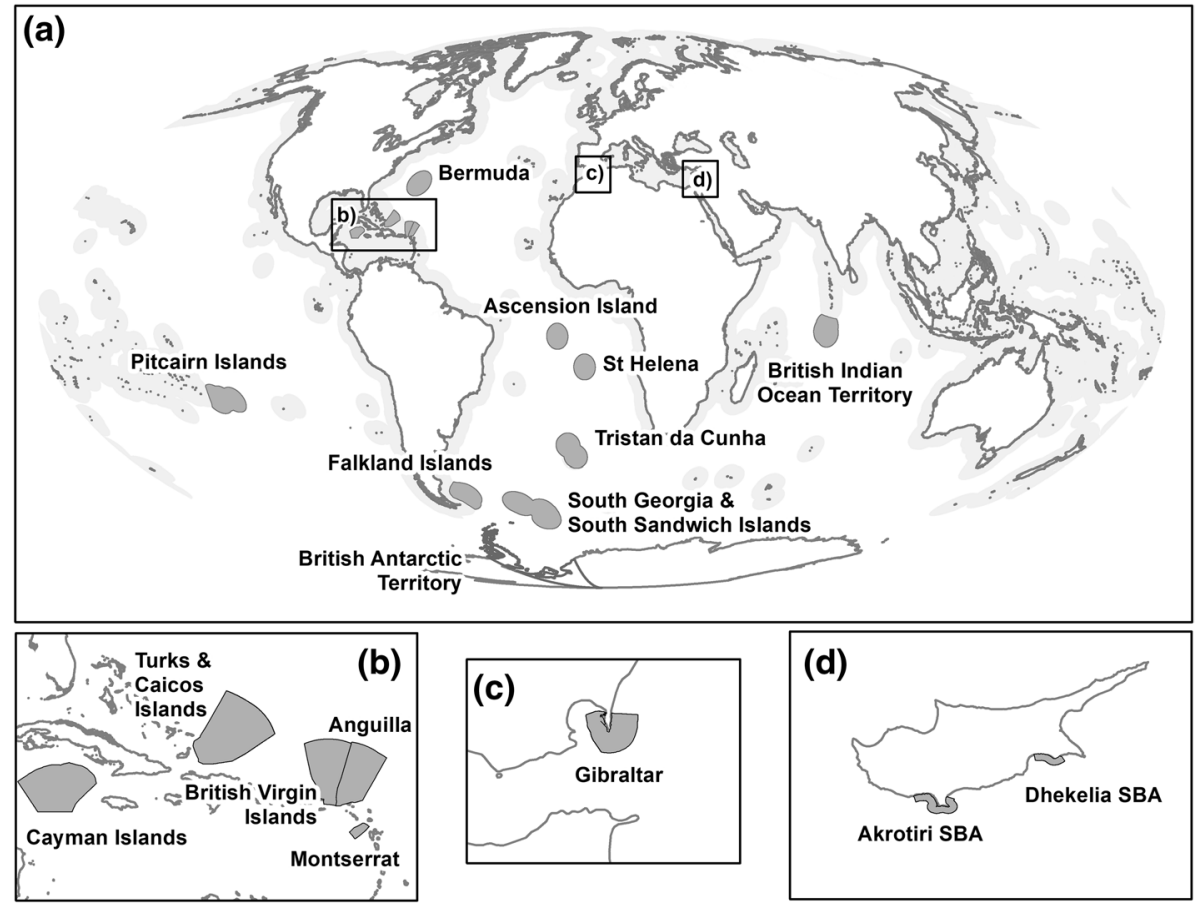

Fig. 1 Marine areas of the United Kingdom's Overseas Territories (UKOTS). World exclusive economic zones are shown in grey scale in map (a). Note that several of the UKOTs are subject to disputes by other countries and that the British Antarctic Territory legally has no marine waters in accordance with the Antarctic Treaty. Sovereign Base Area is abbreviated to SBA in (d)

\section{Introduction}

Scientific evidence is an essential component of the evidence toolkit for informing future research direction and management decisions (Dicks et al. 2014). Incomplete data and limited knowledge, together with inadequate staff and budget capacity, present challenges for ensuring effective conservation and environmental management (Gill et al. 2017; Kingsford et al. 2009). The United Kingdom (UK) government is responsible for approximately $2 \%$ of the world's ocean (approx. 6.8 million $\mathrm{km}^{2}$ ). Just $11 \%$ (approx. 770,000 $\mathrm{km}^{2}$ ) of this lies within the UK's domestic exclusive economic zone (EEZ) with the remainder spread across its 14 Overseas Territories (UKOTs) and their associated waters (Fig. 1). The vast area of marine waters that fall under the jurisdiction of the UKOTs contain a wealth of biodiversity (Churchyard et al. 2016; Dawson et al. 2014; Friedlander et al. 2014; Sheppard et al. 2012; Weber et al. 2014) much of which underpins ecosystem goods and services, predominately fisheries and tourism, upon which local communities, where present, often depend for their livelihoods (e.g. Amoamo 2013; Baker et al. 2015; Forster et al. 2014; Lester et al. 2017). However, a recent stock-take of marine biodiversity out to 12 nautical miles $(\mathrm{nm})$ in the UKOTs concluded that knowledge of their marine species is poor and of variable quality (Churchyard et al. 2016).

The UKOTs largely comprise islands and archipelagos spread across the Atlantic, Indian, Pacific and Southern Oceans, and the Caribbean Sea (Fig. 1). The three exceptions 
are Gibraltar, which is part of the European mainland, and Akrotiri and Dhekelia Sovereign Base Areas and the British Antarctic Territory (BAT) which are part of larger landmasses. All UKOTs have permanent civilian populations apart from BAT, South Georgia and the South Sandwich Islands (SGSSI), and the British Indian Ocean Territory (BIOT). The United Nations has recognised Henderson Island (part of the Pitcairn Islands group) and Gough and Inaccessible Islands (which fall under the jurisdiction of Tristan da Cunha) as World Heritage sites for biodiversity due to their largely intact ecology because of minimal human disturbance and the presence of endemic species, particularly seabirds (UNESCO 1988, 1995).

The UK has committed to the Convention on Biological Diversity's target of protecting at least $10 \%$ of the marine environment by 2020 (Convention on Biological Diversity 2010; also adopted within Sustainable Development Goal 14.5, United Nations 2015). Contributing to this goal, the UK Conservative Party made a manifesto commitment in 2015 to create a 'Blue Belt of marine protection' around the UK and its Overseas Territories (The Conservative Party 2015), and this has now been adopted by the UK's other major political party (The Conservative Party 2017; The Labour Party 2017). Four large-scale marine protected areas (MPAs, $\geq 100,000 \mathrm{~km}^{2}$ ) have already been designated, with plans for two more announced (Table 1). Two of these, the Chagos Archipelago MPA and the Pitcairn Islands Marine Reserve, have been established as full no-take areas, closed to all fishing (Government of Pitcairn Islands 2016; Sheppard et al. 2012). Recognising the importance of resource capacity for effective MPA management (Gill et al. 2017), the UK government committed funds of approximately $£ 20$ million over 4 years at the 2016 Our Ocean conference (Washington DC) to implement and monitor large-scale MPAs around the UKOTs, focusing initially on BIOT, SGSSI, BAT, the Pitcairn Islands, Ascension Island, St Helena, and Tristan da Cunha (UK Government 2017).

Ensuring effective marine management within the UKOTs and the ability to monitor the effectiveness of management actions, such as marine protected areas (MPAs), requires good knowledge of biodiversity and threats facing marine life. However, scientific research conducted within the various UKOTs is presented through a disparate literature and a comprehensive assessment of this and the extent of threats facing UKOTs is currently lacking. Here, we address these issues by systematically searching for scientific literature which has examined marine biodiversity in the UKOTs and by exploring publicly available spatial threat data (Halpern et al. 2015, 2008). The objectives of this study are three-fold: (1) to comprehensively collate and describe marine biodiversity research within the UKOTs to assist decision-makers and researchers in targeting gaps in the evidence base; (2) to broadly identify the main threats affecting marine biodiversity in the UKOTs; and (3) to evaluate the extent to which scientific research is addressing threats facing marine biodiversity within the UKOTs.

\section{Methods}

The UKOTs consist of: Anguilla, the British Virgin Islands (BVI), the Cayman Islands, Montserrat, and the Turks and Caicos Islands (TCI) in the Caribbean; Bermuda in the North-western Atlantic; Ascension, St Helena, and Tristan da Cunha, and the Falkland Islands in the South Atlantic; the British Antarctic Territory (BAT) and South Georgia and the South Sandwich Islands (SGSSI) in the Southern Ocean; the British Indian Ocean Territory (BIOT, also known as Chagos) in the Indian Ocean; Pitcairn, Henderson, Ducie and 


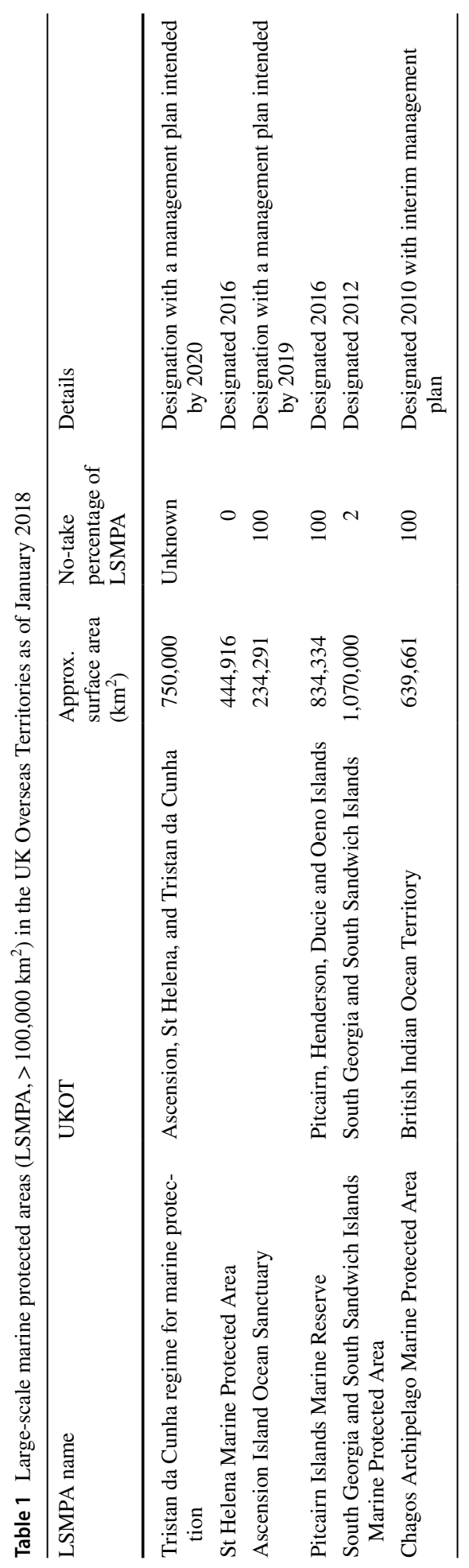


Oeno Islands (also known as the Pitcairn Islands) in the South Pacific; and Gibraltar and the Sovereign Base Areas (SBAs) of Akrotiri and Dhekelia in the Mediterranean. Note that while there are only 14 qualifying territories, these have been separated into 16 analysis areas for the purposes of this study by treating Ascension, St Helena and Tristan da Cunha separately (Fig. 1). Note also that several of the UKOTs are subject to disputes by other countries [Akrotiri and Dhekelia SBAs by Cyprus, BAT by Chile and Argentina, BIOT by Mauritius and Seychelles, Falkland Islands by Argentina, and Gibraltar with Spain, and SGSSI by Argentina (Huth and Allee 2003)] and that BAT legally has no marine waters in accordance with The Antarctic Treaty (1959). We have consequently not undertaken a threat analysis for the waters around BAT, however to provide a comprehensive assessment and ensure future relevance of our research directory we have included waters surrounding BAT within the literature review.

\section{Literature review}

An intensive search of peer-reviewed scientific literature was undertaken in Web of Science and Scopus using the search string: [(Anguilla OR Bermuda OR "British Antarctic Territory" OR BAT OR "British Indian Ocean Territory" OR Chagos OR BIOT OR "Virgin Islands" OR BVI OR (Cayman AND island*) OR "Falkland Islands" OR Gibraltar OR Montserrat OR "Pitcairn Island*” OR "Henderson Island" OR Ducie OR Oeno OR "Saint Helena" OR Ascension OR "Tristan da Cunha” OR "South Georgia” OR "South Sandwich Islands" OR Akrotiri OR Dhekelia OR "Turks and Caicos Islands" OR TCI OR (Turks AND island*) OR (Caicos AND island*) OR [(UK OR "United Kingdom" OR British) AND (“overseas territor*”)] AND (marine OR ocean OR coast*)].

Searches were initially run to capture all potentially relevant articles however only studies published in English and post-2006 were screened to restrict our assessment to the most recent decade of publication and to ensure a manageable return of literature. This represents approximately $50 \%$ of all scientific literature returned. Searches were undertaken between February and August 2017. The results from each search were combined in a single Endnote library file and duplicates removed. Grey literature, research not published in traditional academic journals, were not included within this assessment due to the difficulty in locating it and the time constraints of the study, however see Carine et al. (2015) for an assessment of biodiversity focused literature between 2009 and 2015 for both terrestrial and marine environments.

Retrieved articles were assessed for inclusion in our review according to a hierarchical assessment of relevance by screening article titles and abstracts, then full text of potentially relevant articles (Fig. 2). The aim of this process was to systematically remove articles that did not contain relevant information for our study. Studies were considered relevant if they were undertaken within UKOT marine waters, were of primary research (e.g. field, laboratory, modelling-based) and relevance to present day marine biology, biodiversity, ecology, and/or had a direct marine conservation/management outcome. Relevant reviews of UKOT waters were recorded separately. Note, only articles from, or that report direct use of, UKOT waters are reported. Studies conducted in nearby regions are also likely to be relevant for inference but were not searched for or included when identified.

Summary data (UKOT covered, full article reference, publication year, broad research focus, biological group studied) from each relevant article were extracted into a Microsoft Excel spreadsheet for descriptive analysis. 


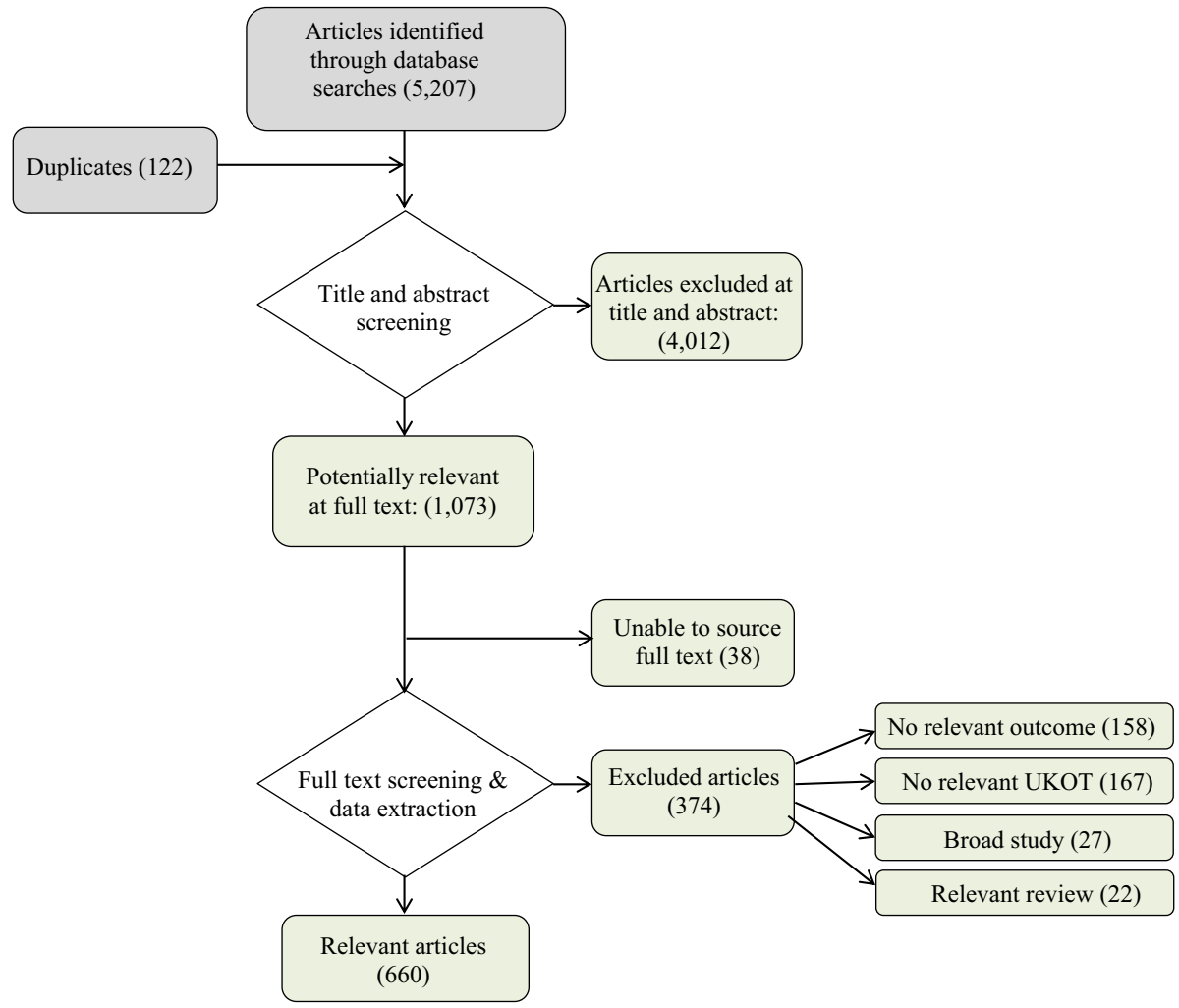

Fig. 2 Schematic of review stages from searches. Grey boxes represent inputs; diamonds: processes; arrows: information flow; and pale green boxes: outputs. Numbers in brackets represent the number of articles involved at each stage

\section{Spatial analysis of biodiversity threats}

UK Overseas Territory marine limits were downloaded from the UK government's Hydrographic Office. ${ }^{1}$ Raw raster data for 19 global anthropogenic stressors to the ocean were used from Halpern et al. (2015) (Table 2). Note that other threats, such as disease (van Woesik and Randall 2017), noise (Haver et al. 2017) and crown-of-thorns outbreaks (Roche et al. 2015), face the UKOT's marine environment but were not considered in the spatial analysis of threats due to a lack of comprehensive spatial data beyond these studies focussed on specific locations. Raw stressor data were clipped to the extent of the UKOTs to remove high intensity values in busier seascapes and scale threats relative to the UKOTs. Stressor data were then transformed using a $\log (x+1)$ to ensure a normal distribution for all layers and rescaled on a continuous scale between 0 and 1 replicating processing methods from Halpern et al. (2008). To enable standardised comparison between stressors, each layer was rescaled using Eq. 1 for pixel i in layer j. This placed each pixel onto a unitless

\footnotetext{
1 UK Hydrographic Office (last updated 2015). UK, UK Overseas Territories and UK Crown Dependencies Maritime Limits and Law of the Sea. [online] www.gov.uk/guidance/uk-maritime-limits-and-law-of-the-sea.
} 


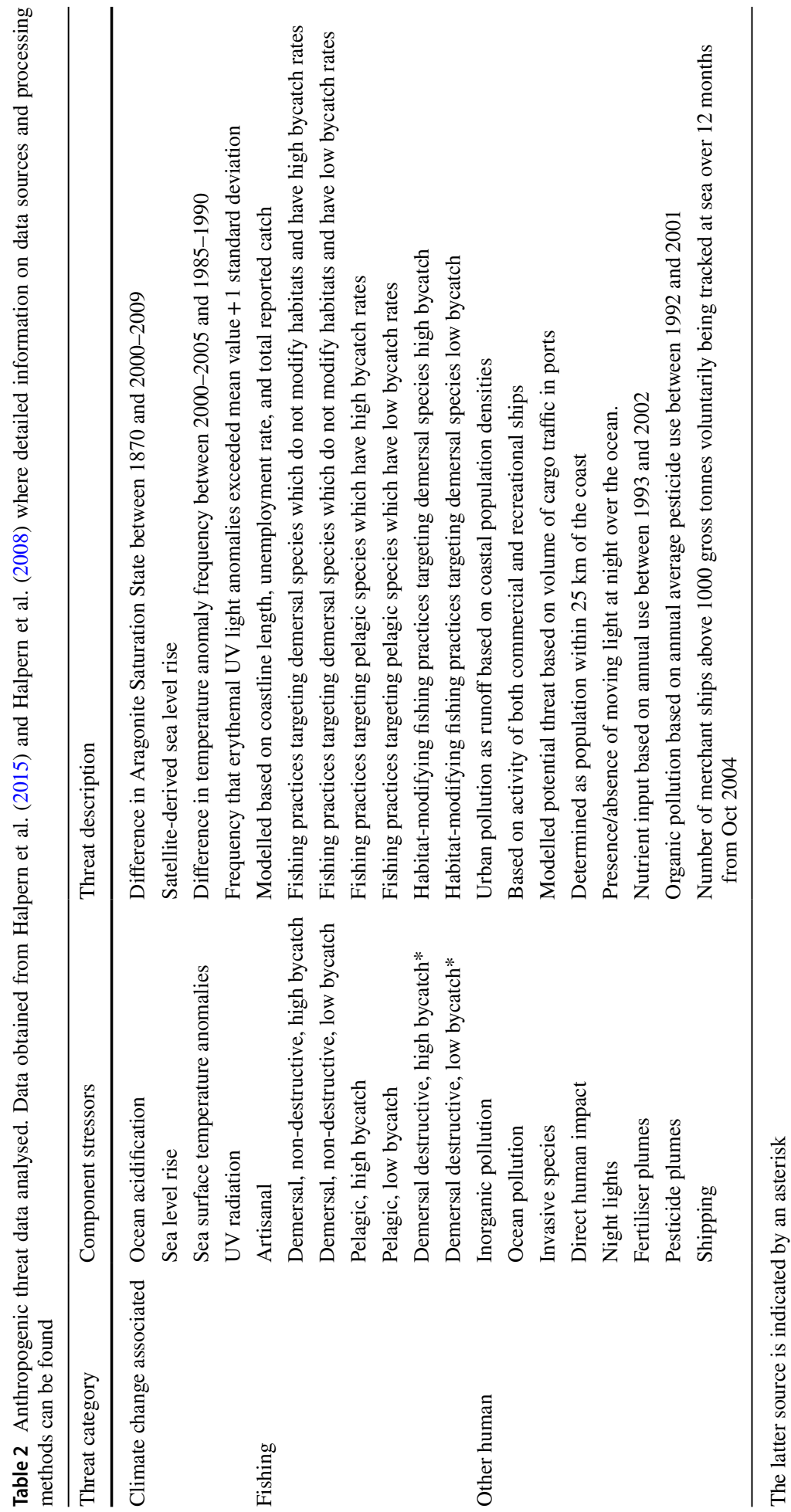


(a)

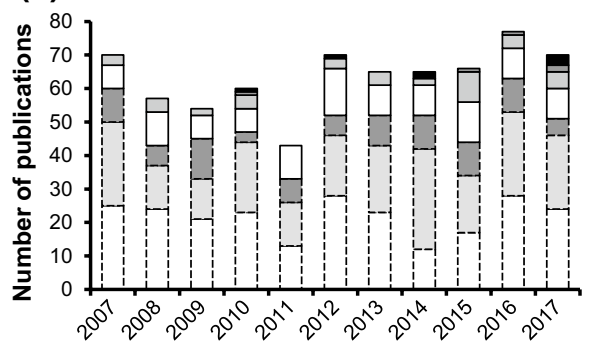

Publication year (b)

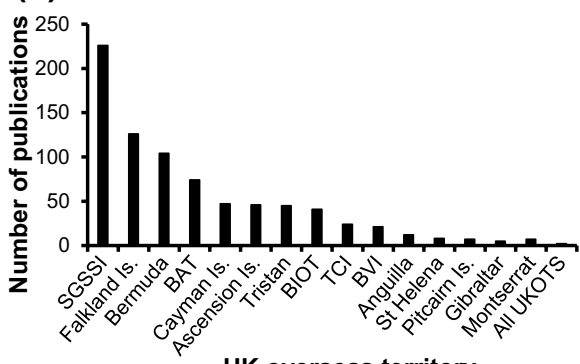

Fig. 3 Distribution of articles included in the review by a publication year, and $\mathbf{b}$ UK Overseas Territory studied. a Articles are categorised by region: white dashed outline Southern Ocean, pale grey dashed outline South Atlantic, dark grey dashed outline Caribbean, white solid outline North-western Atlantic, pale grey solid outline Indian Ocean, dark grey solid outline Mediterranean Sea, black Pacific. b Abbreviations: SGSSI South Georgia and South Sandwich Islands, Is. island(s), BAT British Antarctic Territory, BIOT British Indian Ocean Territory, Tristan Tristan da Cunha, TCI Turks \& Caicos Islands, BVI British Virgin Islands. Akrotiri \& Dhekelia Sovereign Base Areas are not included in $\mathbf{b}$ as no articles were identified in this UKOT

scale between 1 and 0 , where 1 is highest intensity and 0 is lowest intensity, thereby allowing stressors to be ranked and compared against each other.

$$
x=\frac{x_{i}-\min _{j}}{\max _{j}-\min _{j}}
$$

Individual stressors were then combined using a simple additive model to provide an overall threat score of $0-\mathrm{N}$ for $\mathrm{N}$ layers. Note that for the purpose of this study, we assume that stressors are equivalent to threats, however threat level will vary across different activities and within the same activity type, and will affect species and habitats differently. Our results therefore represent an indication of the potential total intensity of threat contributed by all studied stressors facing each UKOT, based on data from Halpern et al. (2015) and Halpern et al. (2008). Although it is acknowledged that all 19 stressors are linked to anthropogenic drivers, similar stressors were divided into three categories for analysis: 'climate change associated' (e.g. sea surface temperature anomalies), 'fishing', and 'other human' (e.g. pollution) stressors (Table 2).

To examine the relative risk to each UKOT, the mean value for each stressor category was extracted and threat levels mapped to explore spatial variability. All data were analysed for each $1 \mathrm{~km}^{2}$ cell of ocean and projected to WGS-1984 Mollweide. Data processing and statistical analysis were conducted in R v.3.4.1 and Microsoft Excel. Spatial analysis was undertaken using ArcGIS 10.4.

\section{Results}

\section{Evidence map generated from the literature review}

We identified 660 relevant articles published between 2007 and August 2017 (Fig. 3a, Table S1). On average 60 articles studying at least one UKOT were published each 


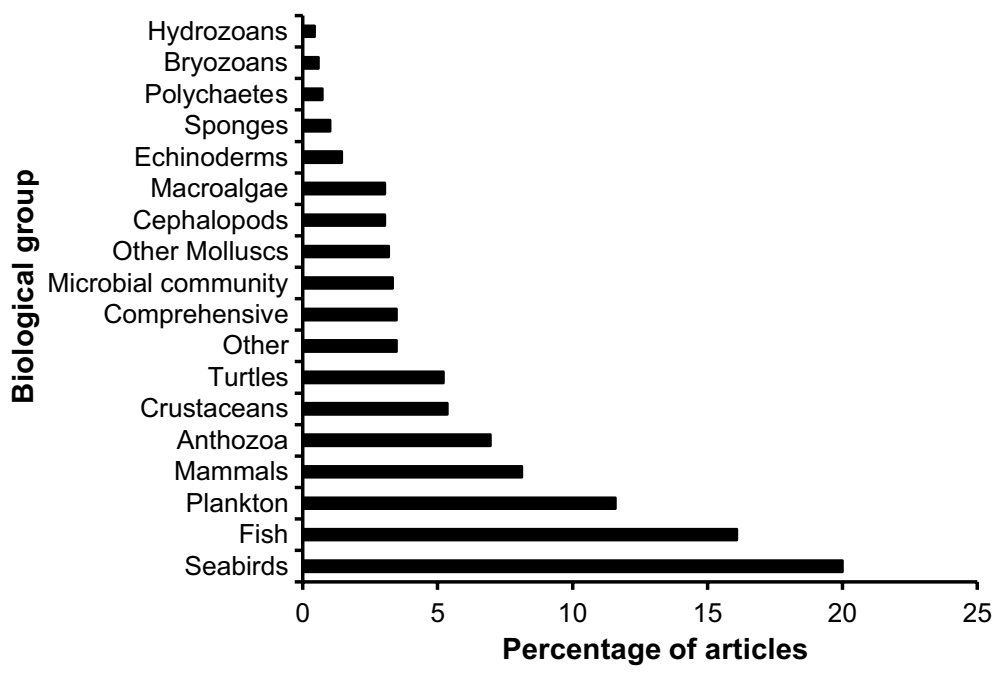

Fig. 4 Percentage of studies in each biological group

year. $69 \%$ of all identified studies are from three territories: South Georgia and the South Sandwich Islands (SGSSI, 34\%), Falkland Islands (19\%), and Bermuda (16\%) (Fig. 3b). UKOTs within the Caribbean collectively only accounted for $13 \%$ of all identified articles. No articles were identified from Akrotiri and Dhekelia Sovereign Base Areas.

The most common biological groups examined were seabirds $(20 \%$ of all identified articles), fish (16\%), plankton (11\%), marine mammals (8\%), and anthozoa (7\%) (Fig. 4). Only a few studies (4\%) comprehensively considered whole ecological communities (Fig. 4). Penguins were the most commonly studied seabird (29\% of all seabird articles) followed by albatross (26\%) and petrels (20\%). Elasmobranchs only featured in $10 \%$ of all articles that studied fish or fish communities. Seals $(47 \%$ of all mammal articles) and whales (30\%) were the most commonly studied marine mammals.

Focal biological groups were unevenly distributed around the UKOTs. Seabirds dominated articles in Tristan da Cunha (53\% of 45 articles) and the Falkland Islands (38\% of 126 articles). Elsewhere, most articles focused on fish in the Cayman Islands (42\% of 47 articles) and BIOT (35\% of 41 articles), and marine mammals (40\% of 5 articles) in Gibraltar. Studies were mostly concerned with biological, ecological and biogeography related questions whereby life history or genetic characteristics, foraging and species distributions and movement patterns featured most highly. Only $10 \%$ $(\mathrm{N}=67)$ of articles explicitly considered management or conservation implications as their main focus. $15 \%(\mathrm{~N}=101)$ of articles addressed at least one threat as part of their research. Fisheries, including directed and non-directed fisheries impacts, were the most commonly considered anthropogenic stressor (4\% of all identified articles) followed by climate change and its associated impacts (4\%), pollution (3\%) and invasive species (2\%). Other threats considered by studies included disease, noise, habitat loss, extreme weather events, and crown-of-thorns outbreaks however a lack of comprehensive spatial data for these threats prevented further spatial analysis. 


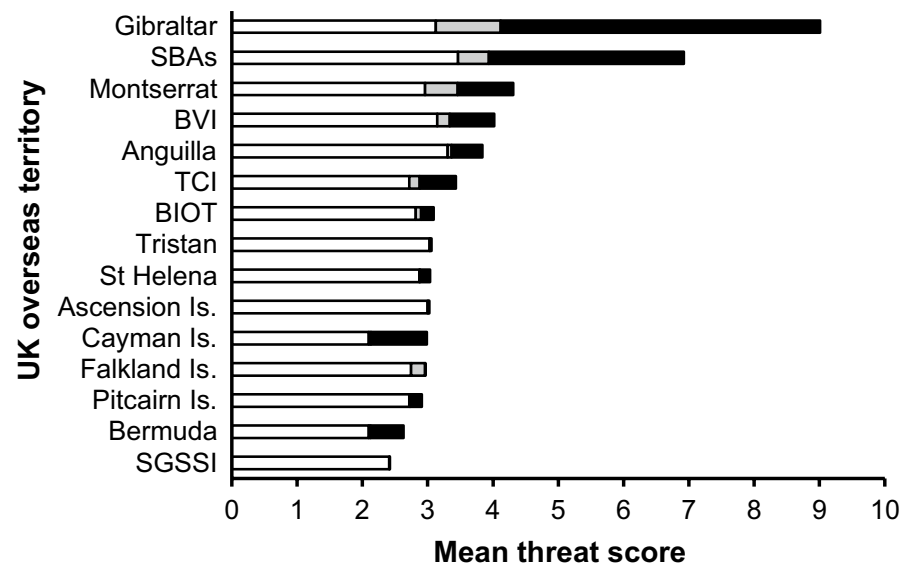

Fig. 5 Mean threat score for each UK Overseas Territory across 'climate change associated' (white), 'fishing' (grey) and 'other human' (black) stressors. Abbreviations: SBAs Akrotiri \& Dhekelia Sovereign Base Areas, BVI British Virgin Islands, TCI Turks \& Caicos Islands, BIOT British Indian Ocean Territory, Is. Island(s), and SGSSI South Georgia and South Sandwich Islands

\section{Spatial analysis of biodiversity threats}

Spatial analyses show 'climate change associated' stressors pose the greatest threat to all the UKOTs with 'fishing' and 'other human' stressors representing lesser threat (Fig. 5). On average, UKOTs within the Mediterranean Sea experience the greatest level of overall mean threat, followed by those within the Caribbean (Fig. 5). However, the intensity of threat varies spatially both within and between UKOTs (Fig. 6). Tristan da Cunha, Anguilla, BVI, Gibraltar and Akrotiri \& Dhekelia SBAs experience the greatest level of mean 'climate change associated' threat and high relative threats across their national waters (Fig. 6a). 'Climate change associated' threat declines towards Antarctica with SGSSI experiencing the lowest level of mean threat compared to the other UKOTs. The majority of UKOT waters experience low relative threat from 'fishing' with areas of concentrated use located around coastlines (e.g. Akrotiri \& Dhekelia SBAs, Caribbean UKOTs), EEZ boundaries (e.g. Pitcairn Islands, BIOT, Caribbean islands, Ascension Island) and high productivity areas (e.g. Falkland Islands) (Fig. 6b). UKOTs within the Caribbean and Mediterranean together with Bermuda experience the greatest level of relative 'other human' stressors across their marine regions (Fig. 6c), although overall levels remain low for most of the UKOTs (Fig. 5).

Sea level rise was the dominant 'climate change associated' stressor across all territories accounting for, on average, more than $30 \%$ of the mean threat score for 'climate change associated' threat across eight of the sixteen territories (Table 3). Mean 'climate change associated' threat scores for the UKOTs were relatively evenly distributed across the three remaining component stressors (Table 2, Table 3). Ocean acidification accounted for between 6 (SGSSI) and 32 (TCI) percent of the mean 'climate change associated' threat facing UKOTs, and explained more than $20 \%$ of the mean 'climate change associated' threat score for twelve territories. Sea surface temperature anomalies and UV radiation each accounted for between approximately 13 and $30 \%$ of the mean 'climate change associated' threat score for each territory. 


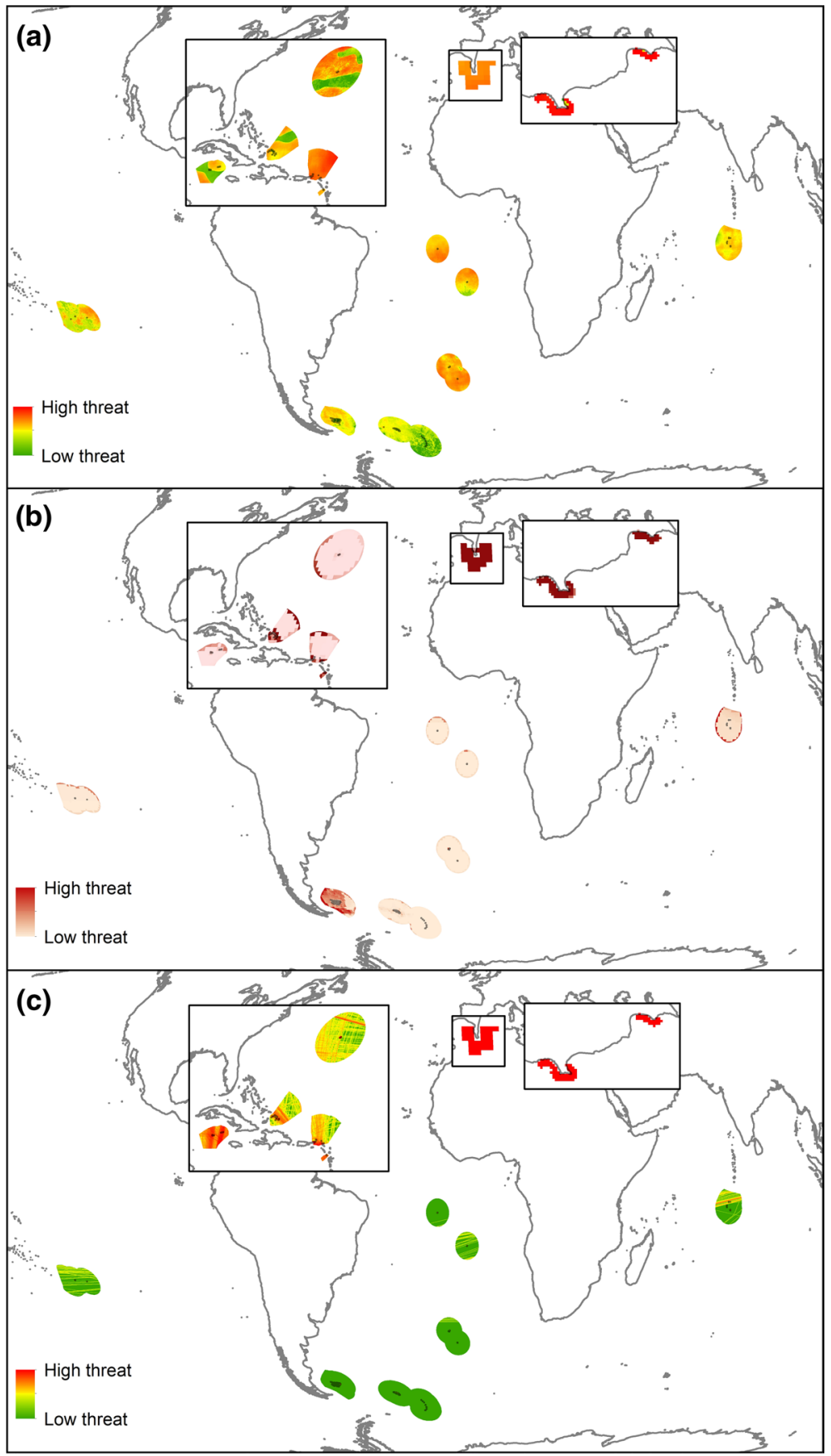

Fig. 6 Additive threat models for a 'climate change associated', b 'fishing', and c 'other human' stressors experienced by UK Overseas Territories 
Table 3 Contribution of each component threat to the mean 'climate change associated', 'fishing' and 'other human' threat scores for each UK Overseas Territory. Black cells represent cases where the component threat contributed $>50 \%$ of the mean threat score for the territory in question, dark grey 30-50\%, midgrey $20-30 \%$, light grey $10-20 \%$, and white $<10 \%$. Dashed horizontal lines group territories into ocean regions. Abbreviations: UKOT UK Overseas Territory, BVI British Virgin Islands, Is. Island(s), TCI Turks and Caicos Islands, Tristan Tristan da Cunha, SGSSI South Georgia and South Sandwich Islands, BIOT British Indian Ocean Territory, and SBAs Akrotiri and Dhekelia Sovereign Base Areas. Note that fishing is no longer legally permitted around BIOT and the Pitcairn Islands. 'Pelagic, low bycatch' fishing is shown as contributing $>50 \%$ of the mean 'fishing' threat score for each of these UKOTs, however this is concentrated around exclusive economic zone (EEZ) boundaries (Fig. 6) and likely represents overlap between high seas and EEZ boundaries

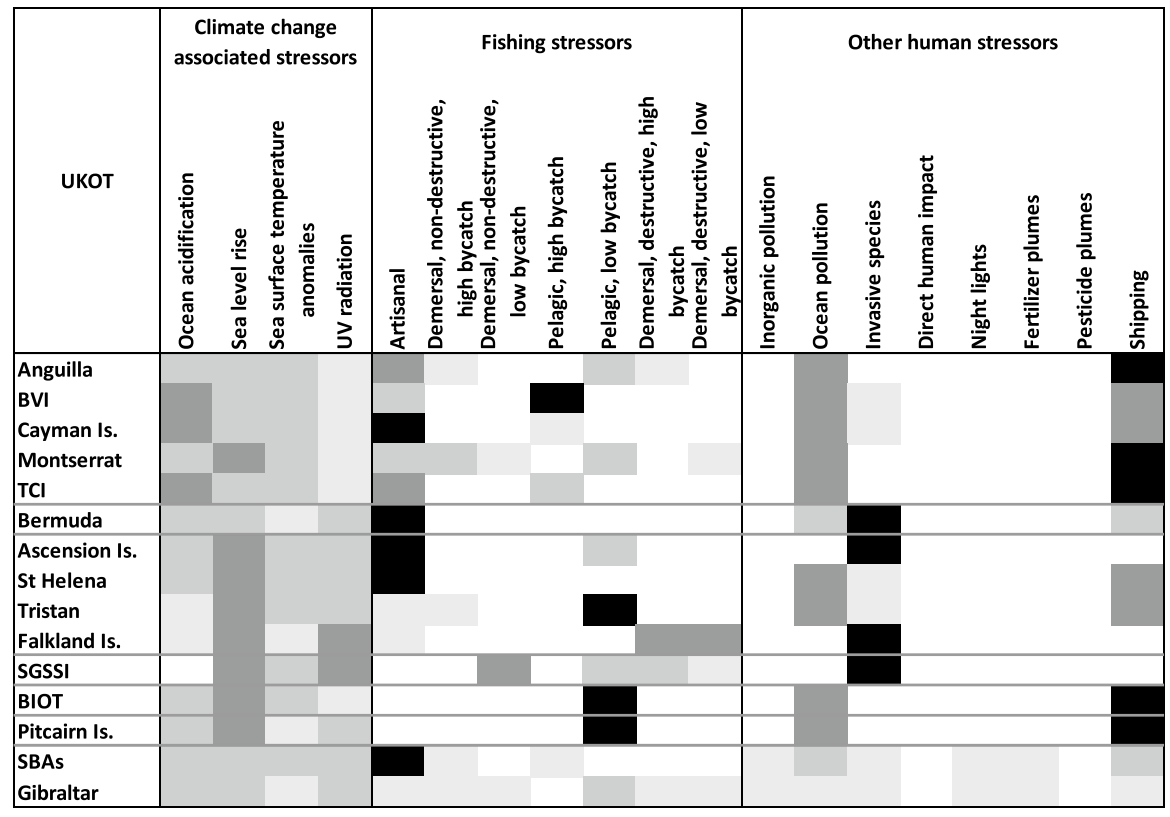

Most UKOTs are subject to one dominant type of component fishing (Table 3). Montserrat and the Falkland Islands present exceptions to this where most of the fishing categories are relatively evenly represented in Montserrat, and two fishing categories ('demersal destructive fishing high' and 'low bycatch') are equally dominant in the Falkland Islands. Artisanal fishing accounts for the greatest proportion of mean 'fishing' threat score for seven of the UKOTs relative to the other component stressors (Table 3). Note that with the establishment of two no-take Large-Scale MPAs, the Chagos Archipelago MPA and the Pitcairn Islands Marine Reserve (Table 1), fishing is no longer legally permitted in the entirety of the exclusive economic zones around BIOT and the Pitcairn Islands, with the exception of halos around the Pitcairn Islands (i.e. Pitcairn, Henderson, Ducie and Oeno islands) and an offshore reef so the local population can continue fishing for subsistence and trade (Government of Pitcairn Islands 2016). 'Pelagic, low bycatch' fishing is shown as contributing $>50 \%$ of the mean 'fishing' threat score for each of these UKOTs (Table 3), however this is concentrated around EEZ boundaries (Fig. 6) and likely represents overlap between high seas and EEZ boundaries.

Ocean pollution and shipping together explain over $70 \%$ of the mean 'other human' stressors threat score for nine of the UKOTs and invasive species accounts for more than $80 \%$ of the mean 'other human' stressors threat score for four of the remaining territories 
(Table 3). However, these component threats are highly interrelated being modelled based on the same raw data (Halpern et al. 2015, 2008). The remaining UKOTs, Gibraltar and the SBAs, have the highest level of 'other human' threat out of all the UKOTs and score consistently highly in all component stressors (Table 3).

Note that many of the UKOTs had no data for one or more areas within their associated waters. Where this occurs, it will lower the mean level of threat for the area concerned and thus make specific locations appear less threatened than others. Further territory-specific analyses would be required to evaluate the extent of these discrepancies as well as to identify particular localised threats and to ground truth modelled data. However, for the purposes of this UKOT-wide analysis, the results presented provide an indication of the main broad threats facing each UKOT relative to the others.

\section{Discussion}

The UKOTs are a geographically disparate group of countries politically aligned by the UK government, although each have local governance. Until now, scientific research has been scattered across a disparate literature base presenting challenges for researchers and decision-makers alike to locate and apply all relevant literature to make informed decisions. The research directory we present (Table S1) provides a resource for end-users to quickly and easily identify recent research relevant to their needs, and it is hoped that this will spur continued efforts to maintain this directory and track research knowledge and focus in the UKOTs.

Overall, we found that marine biodiversity within the UKOTs has received consistent, but largely low, levels of scientific interest over the past 12 years (Fig. 3a) and our findings highlight considerable bias in research effort geographically and in terms of biological focus (Fig. 3, Fig. 4). There is a weak inverse relationship between the mean threat score of a UKOT and the number of scientific publications $(r=-0.458, p>0.05, n=16)$ suggesting that scientific interest is not being driven by immediate threats. Three territories (SGSSI, Falkland Islands and Bermuda) dominate scientific publications, with thirteen of the remaining territories each having fewer than 50 articles published during the study timeframe, and less than 10 each for six of these (Fig. 3). Focus on these three territories is likely, at least in part, due to existing research infrastructure and associated and established research organisations, e.g. the British Antarctic Survey, the South Atlantic Environmental Research Institute, the Bermuda Institute of Ocean Sciences. Greater resources to establish similar infrastructure and expertise across other UKOTs would facilitate more balanced research. Studies on seabirds, fish and plankton account for almost $50 \%$ of the focus of all research, with focal biological groups understandably distributed differently across the territories. Unexpected, however, was the lack of practical management or conservation considerations or focus on anthropogenic threats within research. Instead, research appears to be predominately focused on basic biological questions (e.g. growth, reproduction) and species taxonomy or distribution. The predominance of such studies highlights the lack of knowledge regarding marine life in the UKOTs, particularly with regards informing broader ecosystem-scale management, concurring with Churchyard et al.'s (2016) findings.

Interestingly, apart from the Pitcairn Islands, no evidence of new or renewed interest in marine biodiversity following the announcement or designation of large-scale marine protected areas was found. However, this may be because of the time required for scientific publication and the relative newness of four of these (Table 1). Moreover, many of the 
UKOTs are remote and are difficult and expensive to travel to with most lacking essential research platforms such as survey vessels, although if work can be done locally or in partnership with local communities then costs may be reduced and associated in-country benefits will be greater as local expertise develops. Obtaining the necessary funds to mobilise research equipment and personnel therefore adds an additional lag time, particularly with limited funding sources for work on environmental issues in the UKOTs. Furthermore, considerable work is done in the UKOTs by, or for, non-governmental and governmental organisations (e.g. Dallison and Ferguson 2017; Irving and Dawson 2012; MarEcol 2017) and much valuable knowledge is likely contained in reports produced by these organisations. With publication times of grey literature also likely to be more rapid than formal scientific publications, extension of this work to include grey literature would be beneficial. Given the recent and planned designation of many of the large-scale MPAs in the UKOTs, it is also likely that additional research is in its infancy with few results to report as yet. For example, the Bertarelli Foundation has provided funding from 2017 to 2020 to develop a programme in marine science for BIOT, coordinated by the Zoological Society of London (ZSL), but research results are yet to be published. ${ }^{2}$

This study presents an assessment of the extent and intensity of threats being experienced by the marine environment of the UKOTs, and showed that those with higher human populations experience greater levels of 'fishing' and 'other human' stressors, but that all UKOTs are affected by 'climate change associated' threats. For the majority of UKOTs, fishing appears to be of relatively low threat and highly localised (Fig. 6b). With recent designation of large-scale no-take MPAs covering the EEZs of BIOT and the Pitcairn Islands prohibiting fishing, and stronger marine management around other UKOTs implemented and planned to reduce fishing impacts (Table 1), the challenge is now to ensure effective enforcement to prevent illegal, unreported and unregulated fishing in these areas (O'Leary et al. 2018). Nonetheless, site specific research to ground truth these findings and provide additional threat data to better inform spatial management is required. Our study considered threats within UKOT national waters. However, the high connectivity of the marine environment means that human activities and threats in regions adjacent to UKOT waters can also affect the status of their biodiversity. Illustrating this is the higher level of fishing effort observed around many of the UKOT outer marine limits (Fig. 6b) and further studies may wish to consider external threats such as the regional use of Fish Aggregating Devices (Davies et al. 2014) and pollution incidents (Richardson et al. 2017).

Much effort is spent on research to prioritise areas and species in greatest need of conservation action. However, while species are the building blocks of ecosystems, it is typically not cost-effective to approach conservation on a species-by-species basis, particularly where information is poor (Likens and Lindenmayer 2012). Our findings suggest that research within the UKOTs needs to move beyond target species to ecosystems more broadly, and place greater attention on the effects of anthropogenic impacts on these. This is particularly important given the increasing extent of anthropogenic impacts facing marine environments. For example, climate change has affected UKOTs through bleaching events (McWilliams et al. 2005; Perry et al. 2015) and increased frequency and severity of storms (IPCC 2013, 2014; Shuckburgh et al. 2017). Increasing recognition of the extent of impacts from marine plastics (Boehm et al. 2017; Jambeck et al. 2015) also requires attention within the UKOTs where widespread plastic debris has been reported (e.g. Lavers

\footnotetext{
${ }^{2}$ ZSL (2017) UK Overseas Territories Chagos Archipelago. [online] www.zsl.org/regions/uk-overseas-terri tories/chagos-archipelago.
} 
and Bond 2017; Readman et al. 2013; Walker et al. 1997). Nonetheless, one threat that has received greater publicity and management attention is the impact of invasive mammalian predators (e.g. cats, rats) on seabirds across the UKOTs which have been the subject of eradication schemes (Dawson et al. 2014; Hilton and Cuthbert 2010; Martin and Richardson 2017).

While the logistics of undertaking marine science in many of the remote UKOTs are demanding, the lack of research being undertaken in many of the UKOTS is a matter of concern for decision-makers tasked with undertaking evidence-based marine environmental management. Furthermore, where relevant studies are available, the representativeness of their findings for wider application may be limited due to a lack of replication, limited sample sizes, and discrete sampling.

Box 1: Research and conservation implementation needs in the UKOTs

Effective conservation and management relies on good quality information, underpinned by research and long-term monitoring. However, our research shows there is an inadequate marine scientific evidence base on which to effectively inform marine conservation and management decisions for the UKOTs. Here, we make 3 key recommendations highlighting research and conservation implementation needs in the UKOTs

(1) Expand the evidence directory to include grey literature and encourage greater collaborative research The evidence directory we compile here is limited to scientific publications however much activity is ongoing in the UKOTs beyond academic circles. It would therefore be beneficial to expand the evidence directory to include grey literature published across the UKOTs. Identifying grey literature is, however, time-consuming and requires a clearly designed, comprehensive and transparent strategy (Haddaway and Bayliss 2015) and it will be necessary to ensure adequate resources and capacity to undertake this task. To increase the effectiveness of all forms of scientific investigation in the UKOTs, greater collaborative research is required, and efforts need to address local interests and stakeholder needs. Findings should be widely disseminated and available for interactive use by making datasets and knowledge available and more accessible through scientific channels. This would help prevent duplication of field work, enable evidence gaps to be more effectively targeted, and enhance technical capacity within the UKOTs

(2) Design and undertake research to inform future marine environmental management, particularly on the lessor studied UKOTs and on ecosystem structure, function and response to pressures

Eight of the 14 UKOTs had less than 25 scientific articles published on their marine environment between 2007 and 2017 (Fig. 3b). Knowledge of the marine environment for Akrotiri and Dhekelia Sovereign Base Areas is poorest with no articles identified. Other UKOTs were also poorly studied: for example, Gibraltar was only studied by five articles; Montserrat and the Pitcairn Islands were both studied by only seven articles; and St Helena by eight articles. Few studies comprehensively considered whole ecological communities and there was substantial bias present in the evidence base towards particular biological groups (Fig. 4). Greater efforts are required to direct resources at studies designed to improve ecosystem understanding and generate management-relevant information. To improve research relevance, involvement of policymakers, practitioners, key stakeholder groups, and local communities, where present, is recommended in the early stages of research design.

(3) Increase understanding of territory-specific threats to better target management against current and future pressures

Conservation and management of marine resources requires detailed data, which is currently limited for many of the UKOTs. While the analyses presented within this study allow comparisons to be drawn from across the UKOTs, territory specific analyses are required to ground truth modelled data and to identify particularly localised pressures in the region. Greater research efforts are therefore required to focus on pressures in the UKOTs and in regions connected to UKOT waters to better inform management 


\section{Conclusions}

With the vast majority of the UK's biodiversity contained within its 14 Overseas Territories (FCO 2012), ensuring effective conservation and management will be critical for the UK to meet its international commitments under the Convention on Biological Diversity and Sustainable Development Goal 14. However many UKOTs suffer from a lack of capacity and resources to undertake research or enact conservation and management measures (Churchyard et al. 2016; Forster et al. 2011). Additional and continued investment in research and management is therefore required in the Overseas Territories. Positively, this need is being recognised, with the UK government committing funds to support the implementation and monitoring of large-scale marine protection in the UKOTs, focusing initially on BIOT, SGSSI, BAT, the Pitcairn Islands, Ascension Island, St Helena, and Tristan da Cunha (UK Government 2017). This will help advance scientific and management efforts within these areas.

Loss of biodiversity is recognised as having negative consequences for ecosystem function and service provision (Duffy et al. 2016; Gamfeldt et al. 2015, 2012; Howarth et al. 2014; Oliver et al. 2015; Reich et al. 2012; Soliveres et al. 2016), making biodiversity critical for human health and well-being (Diaz et al. 2006). Effectively managing the marine environment to safeguard against future biodiversity loss will therefore be crucial for continued ecosystem functioning and service provision in the face of changing environmental conditions and an ever-expanding human footprint (Halpern et al. 2015; Roberts et al. 2017; Watson et al. 2013). Areas subject to fewer human activities contain the most intact communities and ecosystems (D'agata et al. 2016; Graham and McClanahan 2013), and so given the remote nature of many of the UKOTs and the relatively low levels of direct anthropogenic threat currently facing marine life in their waters (Fig. 6), there is an opportunity to develop proactive and precautionary marine management. Strategies such as large-scale marine protected areas where appropriate or networks of smaller protected areas contained within more extensive marine spatial plans will be essential to ensure this opportunity is realised (Ban et al. 2017; Boerder et al. 2017; Davies et al. 2017; O'Leary et al. 2018; Spalding et al. 2016). Governments of the UK and its Overseas Territories have made, or are in the process of making, a substantial contribution to global conservation efforts through the designation of large-scale marine protected areas (Table 1), as well as to improved local management (e.g. Augé et al. 2015; Pelembe et al. 2016). Nonetheless, with benefits of protection directly linked to the level of protection given (Edgar et al. 2014) and the extent of that protection (O'Leary et al. 2016b), it is essential that future management ambition matches those of the desired outcomes. Furthermore, while precautionary management is warranted for many of the UKOTs, others with larger human populations may already have degraded marine ecosystems and so conservation efforts are required to focus of preventing further loss and encouraging recovery. Both approaches should be prioritised to maximise the chances of generating improvements to marine ecosystems and local populations, while preventing declines in marine biodiversity elsewhere. This will need to be designed with, and complemented by, other sectoral management measures to deliver the greatest benefits to marine ecosystems and local people (O'Leary et al. 2018).

While we conclude that there is an inadequate scientific marine evidence base to effectively inform marine conservation and management decisions for the UKOTs, policy is also informed by evidence from sources such as expert knowledge, stakeholder reports, and experiential evidence (O'Leary et al. 2016a and references therein), as well as inferred knowledge from other places and the precautionary principle. Nonetheless, there is an 
urgent need to design and undertake research to inform future marine environmental management, and to increase efforts on the lesser studied UKOTs (Box 1). To meet global goals for effective marine management (Convention on Biological Diversity 2010; United Nations 2015), the UK government must ensure greater focus on biodiversity research and management measures across all UKOTs waters.

Acknowledgements This work was funded by the John Ellerman Foundation through a grant to the Great British Oceans campaign. We would like to thank our two reviewers for their constructive comments.

Open Access This article is distributed under the terms of the Creative Commons Attribution 4.0 International License (http://creativecommons.org/licenses/by/4.0/), which permits unrestricted use, distribution, and reproduction in any medium, provided you give appropriate credit to the original author(s) and the source, provide a link to the Creative Commons license, and indicate if changes were made.

\section{References}

Amoamo M (2013) Development on the periphery: a case study of the sub-national island jurisdiction of Pitcairn Island. Asia Pac Viewp 54:91-108. https://doi.org/10.1111/apv.12006

Augé AA, Lascelles B, Dias M (2015) Marine spatial planning for the Falkland Islands. Methodology for identification of important areas for marine megafauna workshop report. South Atlantic Environmental Research Institute, Stanley, Falkland Islands. http://jncc.defra.gov.uk/pdf/MSP_Falkands_FramingWorkshop-report_5-7_April_2016_FINAL.pdf. Accessed 25 Sept 2018

Baker S, Paddock J, Smith AM, Unsworth RKF, Cullen-Wunsworth LC, Hertler H (2015) An ecosystems perspective for food security in the Caribbean: seagrass meadows in the Turks and Caicos Islands. Ecosyst Serv 11:12-21. https://doi.org/10.1016/j.ecoser.2014.07.011

Ban NC, Davies TE, Aguilera SE, Brooks C, Cox M, Epstein G, Evans LS, Maxwell SM, Nenadovic M (2017) Social and ecological effectiveness of large marine protected areas. Glob Environ Change 43:82-91. https://doi.org/10.1016/j.gloenvcha.2017.01.003

Boehm AB, Ismail NS, Sassoubre LM, Andruszkiewicz EA (2017) Oceans in peril: grand challenges in applied water quality research for the 21st century. Environ Eng Sci 34:3-15. https://doi.org/10.1089/ ees.2015.0252

Boerder K, Bryndum-Buchholz A, Worm B (2017) Interactions of tuna fisheries with the Galápagos marine reserve. Mar Ecol Prog Ser 585:1-15. https://doi.org/10.3354/meps12399

Carine M, Gray A, Eaton MA, Hall J, Havery S, Phillips JS, Righton D (2015) Identifying evidence gaps to support the conservation and sustainable management of biodiversity and ecosystem services in the UK overseas territories. Defra Science and Research Project, Project Reference Number: BE0101

Churchyard T, Eaton MA, Havery S, Hall J, Millett J, Farr A, Cuthbert RJ, Stringer C, Vickery JA (2016) The biodiversity of the United Kingdom's Overseas Territories: a stock take of species occurrence and assessment of key knowledge gaps. Biodivers Conserv 25:1677. https://doi.org/10.1007/s1053 $1-016-1149-\mathrm{z}$

Convention on Biological Diversity (2010) COP decision X/2. Strategic plan for biodiversity 2011-2020. https://www.cbd.int/decision/cop/?id=12268. Accessed 25 Sept 2018

D'agata S, Mouillot D, Wantiez L, Friedlander AM, Kulbicki M, Vigliola L (2016) Marine reserves lag behind wilderness in the conservation of key functional roles. Nat Commun 7:12000. https://doi. org/10.1038/ncomms 12000

Dallison T, Ferguson A (2017) Coral Cay Conservation Marine Progress Report Montserrat 2013-2016. https://www.coralcay.org/scientific-research/scientific-reports/. Accessed 28 Aug 2018

Davies TK, Mees CC, Milner-Gulland EJ (2014) The past, present and future use of drifting fish aggregating devices (FADs) in the Indian Ocean. Mar Pol 45:163-170. https://doi.org/10.1016/j.marpo 1.2013.12.014

Davies TE, Maxwell SM, Kaschner K, Garilao C, Ban NC (2017) Large marine protected areas represent biodiversity now and under climate change. Sci Rep 7:9569. https://doi.org/10.1038/s41598-01708758-5 
Dawson J, Oppel S, Cuthbert RJ, Holmes N, Bird JP, Butchart SHM, Spatz DR, Tershy B (2014) Prioritizing islands for the eradication of invasive vertebrates in the United Kingdom overseas territories. Conserv Biol 29:143-153. https://doi.org/10.1111/cobi.12347

Diaz S, Fargione J, Chapin FSI, Tilman D (2006) Biodiversity loss threatens human well-being. PLoS Biol 4:e277. https://doi.org/10.1371/journal.pbio.0040277

Dicks LV, Walsh JC, Sutherland WJ (2014) Organising evidence for environmental management decisions: a '4S' hierarchy. Trends Ecol Evol 29:607-613. https://doi.org/10.1016/j.tree.2014.09.004

Duffy JE, Lefcheck JS, Stuart-Smith RD, Navarrete SA, Edgar GJ (2016) Biodiversity enhances reef fish biomass and resistance to climate change. PNAS 113:6230-6235. https://doi.org/10.1073/pnas.15244 65113

Edgar GJ, Stuart-Smith RD, Willis TJ, Kininmonth S, Baker SC, Banks S, Barrett NS, Becerro MA, Bernard ATF, Berkhout J, Buxton CD, Campbell SJ, Cooper AT, Davey M, Edgar SC, Försterra G, Galván DE, Irigoyen AJ, Kushner DJ, Moura R, Parnell PE, Shears NT, Soler G, Strain EMA, Thomson RJ (2014) Global conservation outcomes depend on marine protected areas with five key features. Nature 506:216-220. https://doi.org/10.1038/nature13022

FCO (2012) The overseas territories: security, success and sustainability. CM8374. https://www.gov.uk/ government/publications/the-overseas-territories-security-success-and-sustainability. Accessed 28 Aug 2018

Forster J, Lake IR, Watkinson AR, Gill JA (2011) Marine biodiversity in the Caribbean UK overseas territories: perceived threats and constraints to environmental management. Mar Pol 35:647-657. https:// doi.org/10.1016/j.marpol.2011.02.005

Forster J, Lake IR, Watkinson AR, Gill JA (2014) Marine dependent livelihoods and resilience to environmental change: a case study of Anguilla. Mar Pol 45:204-212. https://doi.org/10.1016/j.marpo 1.2013.10.017

Friedlander AM, Caselle JE, Ballesteros E, Brown EK, Turchik A, Sala E (2014) The real bounty: marine biodiversity in the Pitcairn Islands. PLoS ONE 9:e100142. https://doi.org/10.1371/journal.pone.01001 42

Gamfeldt L, Snä T, Bagchi R, Jonsson M, Gustafsson L, Kjellander P, Ruiz-Jaen MC, Fröberg M, Stendahl J, Philipson CD, Mikusiński G, Andersson E, Westerlund B, Andrén H, Moberg F, Moen J, Bengtsson J (2012) Higher levels of multiple ecosystem services are found in forests with more tree species. Nat Commun 4:1340. https://doi.org/10.1038/ncomms2328

Gamfeldt L, Lefcheck JS, Byrnes JEK, Cardinale BJ, Duffy JE, Griffin JN (2015) Marine biodiversity and ecosystem functioning: what's known and what's next? Oikos 124:252-265. https://doi. org/10.1111/oik.01549

Gill DA, Mascia MB, Ahmadia GN, Glew L, Lester SE, Barnes M, Craigie I, Darling ES, Free CM, Geldmann J, Holst S, Jensen OP, White AT, Basurto X, Coad L, Gates RD, Guannel G, Mumby PJ, Thomas H, Whitmee S (2017) Capacity shortfalls hinder the performance of marine protected areas globally. Nature 543:665-669. https://doi.org/10.1038/nature21708

UK Government (2017) Introducing the Blue Belt Programme. Foreign \& Commonwealth Office, Centre for Environment, Fisheries and Aquaculture Science, and Marine Management Organisation. www. gov.uk/government/publications/the-blue-belt-programme. Accessed 4 Jan 2018

Government of Pitcairn Islands (2016) Pitcairn islands marine protected area ordinance 2016. http:// www.government.pn/Laws/2016-09-13\%20Pitcairn\%20Islands\%20Marine\%20Protected\%20Are a\%20Ordinance\%202016.pdf. Accessed 25 Sept 2018

Graham NAJ, McClanahan TR (2013) The last call for marine wildnerness? Bioscience 63:397-402. https://doi.org/10.1525/bio.2013.63.5.13

Haddaway NR, Bayliss HR (2015) Shades of grey: two forms of grey literature important for reviews in conservation. Biol Conserv 191:827-829. https://doi.org/10.1016/j.biocon.2015.08.018

Halpern BS, Walbridge S, Selkoe KA, Kappel CV, Micheli F, D’Agrosa C, Bruno JF, Casey KS, Ebert C, Fox HE, Fujita R, Heinemann D, Lenihan HS, Madin EMP, Perry MT, Selig ER, Spalding M, Steneck R, Watson R (2008) A global map of human impact on marine ecosystems. Science 319:948-952. https://doi.org/10.1126/science.1149345

Halpern BS, Frazier M, Potapenko J, Casey KS, Koenig K, Longo C, Lowndes JS, Tockwood RC, Selig ER, Selkoe KA, Walbridge S (2015) Spatial and temporal changes in cumulative human impacts on the world's oceans. Nat Commun 6:7615. https://doi.org/10.1038/ncomms8615

Haver SM, Klinck H, Nieukirk SL, Matsumoto H, Dziak RP, Miksis-Olds JL (2017) The not-so-silent world: measuring Arctic, Equatorial, and Antarctic soundscapes in the Atlantic Ocean. Deep-Sea Res Part I 122:95-104. https://doi.org/10.1016/j.dsr.2017.03.002 
Hilton GM, Cuthbert RJ (2010) The catastrophic impact of invasive mammalian predators on birds of the UK Overseas Territories:a review and synthesis. Ibis 152:443-458. https://doi.org/10.1111/ j.1474-919X.2010.01031.x

Howarth LM, Roberts CM, Thurstan RH, Stewart RH (2014) The unintended consequences of simplifying the sea: making the case for complexity. Fish Fish 15:690-711. https://doi.org/10.1111/ faf.12041

Huth PK, Allee TL (2003) The democratic peace and territorial conflict in the twentieth century. Cambridge Studies in International Relations. Cambridge University Press, Cambridge. https://doi. org/10.1017/CBO9780511491405

IPCC (2013) Climate change 2013: the physical science basis. In: Stocker TF et al. (eds) Contribution of working group I to the fifth assessment report of the intergovernmental panel on climate change. Cambridge University Press, Cambridge, United Kingdom and New York, NY, USA. https://doi. org/10.1017/cbo9781107415324

IPCC (2014) Climate change 2014: impacts, adaptation, and vulnerability. In: Field CB et al. (eds) Part A: Global and sectoral aspects. Contribution of working group II to the fifth assessment report of the intergovernmental panel on climate change. Cambridge University Press, Cambridge, United Kingdom and New York, NY, USA

Irving RA, Dawson TP (2012) The marine environment of the Pitcairn Islands. A report to Global Ocean Legacy, a project of the Pew Environment Group. http://www.pewtrusts.org/en/research-and-analy sis/reports/2012/08/31/the-marine-environment-of-the-pitcairn-islands. Accessed 28 Aug 2018

Jambeck JR, Geyer R, Wilcox C, Siegler TR, Perryman M, Andrady A, Narayan R, Law KL (2015) Plastic waste inputs from land into the ocean. Science 347:768-778. https://doi.org/10.1126/science. 1260352

Kingsford RT, Watson JEM, Lundquist CJ, Venter O, Hughes L, Johnston EL, Atherton J, Gawel M, Keith DA, Mackey BG, Morley C, Possingham HP, Raynor B, Recher HF, Wilson KA (2009) Major conservation policy issues for biodiversity in Oceania. Conserv Biol 23:834-840. https://doi. org/10.1111/j.1523-1739.2009.01287.x

Lavers JL, Bond AL (2017) Exceptional and rapid accumulation of anthropogenic debris on one of the world's most remote and pristine islands. PNAS 114:6052-6055. https://doi.org/10.1073/ pnas. 1619818114

Lester SE, Ruff EO, Mayall K, McHenry J (2017) Exploring stakeholder perceptions of marine management in Bermuda. Mar Pol 84:235-243. https://doi.org/10.1016/j.marpol.2017.08.004

Likens GE, Lindenmayer DB (2012) Integrating approaches leads to more effective conservation of biodiversity. Biodivers Conserv 21:3323-3341. https://doi.org/10.1007/s10531-012-0364-5

MarEcol (2017) South atlantic overseas territories commercial fisheries management review summary. https://ww2.rspb.org.uk/globalassets/downloads/documents/conservation-projects/ukots-hidden-treas ures/2017/summary-south-atlantic-overseas-territories-fisheries-sustainability-report-2017.pdf. Accessed 25 Sept 2018

Martin AR, Richardson MG (2017) Rodent eradication scaled up: clearing rats and mice from South Georgia. Oryx:1-9 https://doi.org/10.1017/s003060531700028x

McWilliams JP, Côté IM, Gill JA, Sutherland WJ, Watkinson AR (2005) Accelerating impacts of temperature-induced coral bleaching in the Caribbean. Ecology 86:2055-2060. https://doi. org/10.1890/04-1657

O'Leary BC, Kvist K, Bayliss HR, Derroire G, Healey JR, Hughes K, Kleinschroth F, Sciberras M, Woodcock P, Pullin AS (2016a) The reliability of evidence review methodology in environmental science and conservation. Environ Sci Policy 64:75-82. https://doi.org/10.1016/j.envsci.2016.06.012

O'Leary BC, Winther-Janson M, Bainbridge JM, Aitken J, Hawkins JP, Roberts CM (2016b) Effective coverage targets for ocean protection. Conserv Lett 9:398-404. https://doi.org/10.1111/conl.12247

O'Leary BC, Ban NC, Fernandez M, Friedlander AM, García-Borboroglu P, Golbuu Y, Guidetti P, Harris JM, Hawkins JP, Langlois T, McCauley DJ, Pikitch EK, Richmond RH, Roberts CM (2018) Addressing criticisms of large-scale marine protected areas. Bioscience 68:359-370. https://doi.org/10.1093/ biosci/biy021

Oliver TH, Isaac NJB, August TA, Woodcock BA, Roy DB, Bullock JM (2015) Declining resilience of ecosystem functions under biodiversity loss. Nat Commun 8:10122. https://oi.org/10.1038/ncomms10122

Pelembe T, Ponteen A, Roger-Ryan L, Gregory A (2016) T2T Montserrat report. http://jncc.defra.gov.uk/ pdf/OT_T2T_Montserrat_Workshop_report(WEB).pdf. Accessed 25 Sept 2018

Perry CT, Murphy GN, Graham NAJ, Wilson SK, Januchowski-Hartley FA, East HK (2015) Remote coral reefs can sustain high growth potential and may match future sea-level trends. Sci Rep 5:18289. https:// doi.org/10.1038/srep18289

Readman JW, DeLuna F, Ebinghaus R, Guzman A, Price ARG, Readman EE, Sheppard ALS, Sleight VA, Sturm R, Thompson RC, Tonkin A, Wolschke H, Wright RJ, Sheppard CRC (2013) 
Contaminants, pollution and potential anthropogenic impacts in Chagos/BIOT. In: Sheppard C (ed) Coral reefs of the United Kingdom Overseas Territories. Springer, Dordrecht, pp 283-298. https://doi. org/10.1007/978-94-007-5965-7_21

Reich PB, Tilman D, Isbell F, Mueller K, Hobbie SE, Flynn DFB, Eisenhauer N (2012) Impacts of biodiversity loss escalate through time as redundancy fades. Science 336:589-592. https://doi.org/10.1126/ science. 1217909

Richardson K, Haynes D, Talouli A, Donoghue M (2017) Marine pollution originating from purse seine and longline fishing vessel operations in the Western and Central Pacific Ocean, 2003-2015. Ambio 46:190-200. https://doi.org/10.1007/s13280-016-0811-8

Roberts CM, O’Leary BC, McCauley DJ, Cury P, Duarte CM, Lubchenco J, Pauly D, Sáenz-Arroyo A, Sumaila UR, Wilson RW, Worm B, Castilla JC (2017) Marine reserves can mitigate and promote adaptation to climate change. PNAS 114:6167-6175. https://doi.org/10.1073/pnas.1701262114

Roche RC, Pratchett MS, Carr P, Turner JR, Wagner D, Head C, Sheppard CRC (2015) Localized outbreaks of Acanthaster planci at an isolated and unpopulated reef atoll in the Chagos Archipelago. Mar Biol 162:1695-1704. https://doi.org/10.1007/s00227-015-2708-7

Sheppard CRC, Ateweberhan M, Bowen BW, Carr P, Chen CA, Clubbe C, Craig MT, Ebinghaus R, Eble J, Fitzsimons N, Gaither MR, Gan C-H, Gollock M, Guzman N, Graham NAJ, Harris A, Jones R, Keshavmurthy S, Koldewey H, Lundin CG, Mortimer JA, Obura D, Pfeiffer M, Price ARG, Purkis SJ, Raines P, Readman JW, Riegl B, Rogers A, Schleyer M, Seaward MRD, Sheppard ALS, Tamelander J, Turner JR, Visram S, Vogier C, Vogt S, Wolschke G, Yang JM-C, Yang S-Y, Yesson C (2012) Reefs and islands of the Chagos Archipelago, Indian Ocean: why it is the world's largest no-take marine protected area. Aquat Conserv 22:232-261. https://doi.org/10.1002/aqc.1248

Shuckburgh E, Mitchell D, Stott P (2017) Hurricanes Harvey, Irma and Maria: how natural were these 'natural disasters'? Weather 72:353-354. https://doi.org/10.1002/wea.3190

Soliveres S, Van Der Plas F, Manning P, Prati D, Gossner MM, Renner SC, Alt F, Arndt H, Baumgartner V, Binkenstein J, Birkhofer KLU, Blaser S, Blüthgen N, Boch S, Böhm S, Börschig C, Buscot F, Diekötter T, Heinze J, Hölzel N, Jung K, Klaus VH, Kleinebecker T, Klemmer S, Krauss J, Lange M, Morris EK, Müller J, Oelmann Y, Overmann J, Pašalić E, Rillig MCS, Schaefer HM, Schloter M, Schmitt B, Schöning I, Schrumpf M, Sikorski J, Socher SA, Solly EF, Sonnemann I, Sorkau E, Steckel J, SteffanDewenter I, Stempfhuber B, Tschapka M, Türke M, Venter PC, Weiner CN, Weisser WW, Werner M, Westphal C, Wilcke W, Wolters V, Wubet T, Wurst S, Fischer M, Allan E (2016) Biodiversity at multiple trophic levels is needed for ecosystem multifunctionality. Nature 536:456. https://doi.org/10.1038/ nature 19092

Spalding MD, Meliane I, Bennett NJ, Dearden P, Patil PG, Brumbaugh RD (2016) Building towards the marine conservation end-game: consolidating the role of MPAs in a future ocean. Aquat Conserv 26:185-199. https://doi.org/10.1002/aqc.2686

The Antarctic Treaty (1959) The Antarctic treaty. Conference on Antarctica Washington D.C.-October 15, 1959. www.ats.aq/e/ats.htm. Accessed 25 Sept 2018

The Conservative Party (2015) The Conservative Party Manifesto 2015. https://www.bond.org.uk/data/files/ Blog/ConservativeManifesto2015.pdf. Accessed 30 Aug 2017

The Conservative Party (2017) The Conservative Party Manifesto 2017. https:/www.conservatives.com/ manifesto. Accessed 30 Aug 2017

The Labour Party (2017) The Labour Party Manifesto 2017. https://labour.org.uk/manifesto/. Accessed 25 Sept 2018

UNESCO (1988) World Heritage List: Henderson Island (ref 487). United Nations Educational, Scientific and Cultural Organisation World Heritage Centre. http://whc.unesco.org/en/list/487. Accessed 17 Aug 2017

UNESCO (1995) World Heritage List: Gough and inaccessible Islands (ref 740bis). United Nations Educational, Scientific and Cultural Organisation World Heritage Centre. http://whc.unesco.org/en/list/740. Accessed 28 Aug 2017

United Nations (2015) Sustainable development goal 14: conserve and sustainable use the oceans, seas, and marine resources for sustainable development. https://sustainabledevelopment.un.org/sdg14. Accessed 2 Mar 2017

van Woesik R, Randall CJ (2017) Coral disease hotspots in the Caribbean. Ecosphere 8:e01814. https://doi. org/10.1002/ecs2.1814

Walker TR, Reid K, Arnould JPY, Croxall JP (1997) Marine debris surveys at Bird Island, South Georgia 1990-1995. Mar Pollut Bull 34:61-65. https://doi.org/10.1016/S0025-326X(96)00053-7

Watson RA, Cheung WWL, Anticamara JA, Sumaila RU, Zeller D, Pauly D (2013) Global marine yield halved as fishing intensity redoubles. Fish Fish 14:493-503. https://doi.org/10.111 1/j.1467-2979.2012.00483.x 
Weber SB, Weber N, Ellick J, Avery A, Frauenstein R, Godley BJ, Sim J, Williams N, Broderick AC (2014) Recovery of the South Atlantic's largest green turtle nesting population. Biodivers Conserv 23:30053018. https://doi.org/10.1007/s10531-014-0759-6

\section{Affiliations}

Bethan C. O'Leary ${ }^{1}(1)$ Philip Fieldhouse ${ }^{1} \cdot$ Colin J. McClean $^{1}(1) \cdot$ Adriana E. S. Ford $^{2}(1) \cdot$ Polly Burns ${ }^{1}$. Julie P. Hawkins ${ }^{1}$. Callum M. Roberts ${ }^{1}$ (])

1 Department of Environment and Geography, University of York, Wentworth Way, York YO10 5NG, UK

2 Greenwich Maritime Centre, Old Royal Naval College, University of Greenwich, London SE10 9LS, UK 